\title{
Efektivitas Strategi Pembelajaran Aktif Quiz Team terhadap Hasil Belajar Menelaah Teks Biografi Siswa Kelas X SMK Negeri 2 Medan Tahun Ajaran 2018/2019
}

\author{
Shella Shefty Rizqi ${ }^{1}$, Abdurahman Adisaputera ${ }^{2}$ \\ Universitas Negeri Medan \\ Pendidikan Bahasa dan Sastra Indonesia, Fakultas Bahasa dan Seni, Medan \\ ${ }^{1}$ shella.shefty@gmail.com, ${ }^{2}$ abas 750@yahoo.com
}

\begin{abstract}
Abstrak
Penelitian ini bertujuan untuk mengetahui efektivitas strategi pembelajaran aktif Quiz Team terhadap hasil belajar menelaah teks biografi siswa kelas X SMK Negeri 2 Medan tahun ajaran 2018/2019. Sampel yang diambil adalah kelas X TG2 berjumlah 30 siswa. Metode yang digunakan adalah metode penelitian kuantitatif dengan bentuk eksperimen dan penelitian deskriptif dengan tipe tes awal-tes akhir kelompok tunggal (the one group pre-test-post-test). Nilai rata-rata pre-test siswa yaitu sebesar 47,83 dengan kategori kurang, dan tidak memenuhi KKM yaitu sebesar 75, sedangkan nilai rata-rata post-test siswa yaitu sebesar 79,67 dengan kategori baik dan telah memenuhi KKM. Sebelum dilakukan pengujian data terlebih dahulu dilakukan uji persyaratan analisis yaitu uji normalitas dan uji homogenitas. Berdasarkan hasil analisis, diperoleh bahwa data berdistribusi normal. Setelah dilakukan perhitungan uji normalitas $L_{\text {hitung }}>L_{\text {tabel }}$ pada taraf signifikan, hasil uji normalitas data pre-test adalah (yaitu 0,127 < 0,161), hasil uji normalitas data post-tes tadalah $(-0,022<0,161)$. Hasil uji homogenitas hasil belajar menelaah teks biografi siswa adalah $F_{\text {hitung }}<F_{\text {tabel }}$ yakni 1,38<4,19 dan uji hipotesis thitung $>t_{\text {tabel }}$ yaitu 13,9>2,04, sehingga hipotesis nihil $\left(H_{0}\right)$ ditolak dan hipotesis alternatif $\left(H_{a}\right)$ diterima. Jadi, dapat disimpulkan bahwa strategi pembelajaran aktif Quiz Team efektif terhadap hasil belajar menelaah teks biografi siswa kelas X SMK Negeri 2 Medan tahun ajaran 2018/2019.
\end{abstract}

Kata Kunci: Teks Biografi, Quiz Team

\section{PENDAHULUAN}

Pendidikan merupakan salah satu aspek yang sangat penting bagi semua orang dan tidak dapat dipisahkan dalam kehidupan kita sehari-hari, baik dalam keluarga maupun masyarakat. Di zaman modern saat ini, perkembangan ilmu pengetahuan dan teknologi menuntut adanya sumber daya manusia yang berkualitas, yang mampu menghadapi berbagai tantangan dan mampu bersaing. Suatu negara dapat mencapai sebuah 
kemajuan jika pendidikan dalam negara itu baik kualitasnya. Tinggi atau rendahnya kualitas pendidikan dalam suatu negara dipengaruhi oleh banyak faktor misalnya dari kurikulum, siswa, pengajar, sarana prasarana, dan juga karena faktor lingkungan. Saat ini berpedoman pada kurikulum 2013, kurikulum 2013 merupakan hasil pengembangan dari pemerintah melanjutkan kurikulum terdahulu. Aspek yang disempurnakan dalam kurikulum 2013 adalah Standar Kompetensi Lulusan (SKL), Kompetensi Isi (KI), Kompetensi Dasar (KD). SKL yaitu standar kompetensi lulusan merupakan profil lulusan yang diimplikasikan untuk dimiliki oleh setiap siswa ketika ia lulus dari suatu jenjang pendidikan baik (SD, SMP, SMA). Dalam SKL terdapat tiga ranah yaitu sikap, pengetahuan dan keterampilan.

Arah pembelajaran bahasa Indonesia dalam kurikulum 2013 adalah meningkatkan kemampuan komunikasi melalui berbagai genre teks. Untuk mewujudkannya siswa harus mampu menganalisis atau menelaah berbagai genre teks. Dengan membaca, siswa mampu menelaah suatu teks, baik dari segi kata maupun struktur kalimatnya, sehingga menghasilkan sebuah pemikiran baru berdasarkan apa yang ada di dalam bacaan tersebut. Jenis teks yang dipelajari pada siswa kelas $\mathrm{X}$ dalam pembelajaran bahasa Indonesia kurikulum 2013 adalah Teks Laporan Observasi, Teks Anekdot, Hikayat, Teks Negoisasi, Debat dan Teks Biografi. Dalam menelaah suatu teks, siswa dituntut untuk cermat dan teliti. Hal ini yg tentunya menjadi kendala bagi siswa. Banyak siswa yang beranggapan bahwa kegiatan menganalisis atau menelaah merupakan kegiatan yang sangat rumit dan membosankan. Teks Biografi merupakan salah satu materi yang terdapat dalam silabus kurikulum 2013 kelas X semester genap.

Teks biografi adalah teks yang menceritakan perjalanan hidup seorang tokoh dan memiliki pesan atau nilai keteladanan bagi pembacanya. Dalam bahasa Indonesia, pembelajaran teks biografi menjadi sangat penting karena dapat membuat siswa mengikuti keteladanan dari seorang tokoh. Hal itu dikarenakan biografi mengungkapkan kisah hidup seseorang. Setiap orang pasti memiliki keunikan dan berbeda kisah hidupnya. Kisah hidup itulah yang akan menginspirasi orang lain, termasuk siswa yang membacanya. Zabadi (dalam Sutejo 2013:37) mengungkapkan, agar tidak melupakan jasa dan semangat para inspirator bangsa, kita perlu mengetahui biografinya. Dengan membaca biografi dari seorang tokoh sehingga dapat membentuk karakter yang cerdas dan berakhlak mulia untuk tujuan pendidikan 
dan merupakan wujud nyata dari terealisasinya kurikulum 2013. Di dalam kurikulum 2013 pembelajaran teks biografi terdapat pada K.D 3.14 Menilai hal yang dapat diteladani dari teks biografi.

Peneliti melakukan observasi di SMK Negeri 2 Medan dengan melakukan wawancara yang dilakukan kepada guru bahasa Indonesia Ibu Siti Ferisa Zain Guci, S.Pd., beliau menungkapkan bahwa kenyataan yang ditemukan di SMK Negeri 2 Medan, mengenai proses pembelajaran pada materi teks biografi, diketahui bahwa nilai rata-rata kelas yang diperoleh siswa adalah 55,89. Dari 30 siswa hanya 10 siswa yang telah tuntas belajar dengan Kriteria Ketuntasan Minimal (KKM) yang telah ditentukan yaitu 75 , dan sebanyak 20 siswa belum tuntas belajar dan mencapai KKM. Merujuk pada data tersebut, maka hasil belajar siswa pada mata pelajaran Bahasa Indonesia pada materi teks biografi di kelas X TG 2 SMK Negeri 2 Medan belum dikatakan berhasil. Mulyasa (2013: 131) menyebutkan bahwa suatu pembelajaran dikatakan berhasil apabila sekurang-kurangnya $75 \%$ dari seluruh siswa di kelas telah mencapai KKM.

Penerapan Strategi pembelajaran sangat berpengaruh di dalam kelas untuk menimbulkan keaktifan siswa, namun ternyata guru disana jarang menggunakan strategi pembelajaran sering menggunakan metode ceramah karena menurut beliau, strategi pembelajaran akan memakan waktu yang sangat lama sehingga takutnya materi yang disampaikan belum selesai namun bel sudah berbunyi. Padahal sebenarnya tidak semua strategi pembelajaran memakan waktu yang lama, banyak strategi pembelajaran yang bisa diterapkan dengan waktu yang singkat, tergantung refrensi strategi yang akan digunakan oleh guru. Selain permasalahan di atas, dalam pembelajaran bahasa Indonesia kurikulum 2013 yang berbasis teks, guru sering memberikan teks-teks yang baru namun minat baca siswa kurang terhadap teks yang diberikan. Permasalahan pembelajaran tersebut mengakibatkan tujuan pembelajaran menelaah teks biografi belum tercapai dengan baik dan hasil belajar siswa dalam menelaah teks biografi masih rendah, nilai mereka kebanyakan di bawah rata-rata. Beliau mengungkapkan siswa sulit mengingat materi pada bagian Ciri, Struktur dan Pola penyajian Teks Biografi yang terdapat pada $\mathrm{KD} 3.14$, sehingga hasil belajar mereka pada saat ujian kebanyakan dibawah rata-rata.

Dari uraian permasalahan di atas diketahui bahwa perbaikan proses pembelajaran dapat meningkatkan hasil belajar siswa. Hasil belajar adalah polapola perbuatan, nilai-nilai, pengertian- 
pengertian, sikap-sikap, apresiasi dan keterampilan. Hasil belajar merupakan perubahan perilaku secara keseluruhan bukan hanya salah satu aspek potensi kemanusiaan saja. Menelaah teks biografi adalah penyelidikan untuk mengidentifikasi ciri, struktur, dan pola penyajian karakter unggul dalam teks biografi. Menelaah teks biografi perlu dikuasai siswa. Namun, pada kenyataannya siswa masih mengalami kesulitan dalam memahami pembelajaran menelaah teks biografi ini, dikarenakan guru kurang menggunakan inovasi strategi pembelajaran sehingga menyebabkan siswa menjadi pasif dalam proses pembelajaran. Agar hasil belajar siswa meningkat dalam menelaah teks biografi, diharapkan guru dapat menggunakan strategi pembelajaran yang tepat dan dapat meningkatkan keterlibatan dan keaktifan siswa dalam pembelajaran. Salah satu pendekatan kolaboratif untuk bahasa indonesia yang menunjang bagi siswa adalah active Learning, karena berdasarkan penelitian yang dilakukan oleh Iwan, dkk, (2016), menunjukkan bahwa siswa yang melakukan pembelajaran active learning lebih efektif prestasi belajarnya, lebih termotivasi dan percaya diri dalam bertanya jika dibandingkan dengan model pembelajaran konvensional. Salah satu strategi pembelajaran aktif yang dapat mengaktifkan siswa dalam pembelajaran adalah strategi Quiz Team.

Quiz Team adalah salah satu strategi pembelajaran active learning. Strategi Quiz Team dikembangkan oleh Mel Silberman yang berfungsi menghidupkan suasana dalam proses belajar. Dalam menggunakan Strategi pembelajaran Quiz Team ini siswa diharapkan dapat lebih aktif baik bertanya maupun menjawab pertanyaan. Menurut Istarani (2011:211) strategi Team Quiz atau Quiz kelompok adalah strategi yang dilakukan guru untuk dapat meningkatkan tanggung jawab belajar peserta didik dalam suasana yang lebih menyenangkan. Sedangkan Menurut Silberman (2007:4950) strategi Quiz Team dapat meningkatkan kemampuan tanggung jawab peserta didik terhadap apa yang mereka pelajari melalui cara yang menyenangkan dan tidak menakutkan. Proses belajar mengajar dengan strategi team quiz mengajak siswa bekerja sama dengan teamnya dalam melakukan diskusi bertanya, menjawab pertanyaan,memberi arahan, mengemukakan pendapat, serta menyampaikan informasi. Kegiatan tersebut akan melatih keterampilan siswa dan juga memperdalam pemahaman konsep siswa.

Beberapa penelitian menunjukkan bahwa strategi pembelajaran aktif Quiz Team efektif dilakukan untuk 
mempengaruhi pemahaman siswa. Salah satunnya penelitian yang dilakukan oleh Pratiwi Wiwit, dkk tahun (2014) dengan judul Penerapan Metode Pembelajaran Quiz Team Untuk Meningkatkan Aktivitas Dan Prestasi Belajar Siswa Pada Materi Kelarutan Dan Hasil Kali Kelarutan Di Kelas Xi Ipa 2 Sma Al Islam 1 Surakarta Tahun Ajaran 2014/2015. Dari penelitian tersebut diperoleh hasil bahwa penggunaan model Quiz Team dapat meningkatkan hasil belajar siswa dengan presentase ketuntasan mencapai $41,18 \%$ pada siklus I dan meningkat menjadi $82,35 \%$ pada siklus II. Senada dengan penelitian di atas, Kusmantoro (2015) dengan judul Penerapan Quiz Team Untuk Meningkatkan Keaktifan dan Prestasi Belajar Matematika Siswa Kelas X-6 SMA Negeri I Imogiri. Dari penelitian tersebut diperoleh hasil bahwa strategi pembelajaran Quiz Team dapat meningkatkan keaktifan dan prestasi belajar matematika siswa kelas X 6 SMA Negeri 1 Imogiri dengan presentase ketuntasan mencapai $56,4 \%$ pada siklus I dan meningkat menjadi $84,56 \%$ padasiklus II.Oleh sebab itu, berdasarkan pemaparan di atas, penulis tertarik melakukan penelitian dengan judul "Efektivitas Strategi Pembelajaran Aktif Quiz Team terhadap Hasil Belajar Menelaah Teks Biografi Siswa Kelas X SMK Negeri 2 Medan Tahun Pelajaran 2018/2019”.

\section{KAJIAN TEORI}

\section{Strategi Pembelajaran Aktif}

Hamdani (2011:48) menyatakan bahwa strategi active learning adalah strategi belajar mengajar yang bertujuan meningkatkan mutu pendidikan. Untuk mencapai keterlibatan siswa agar afektif dan efisien dalam belajar, yaitu dari sudut siswa, guru, situasi belajar, program belajar, dan dari sarana belajar. Silberman (2006:10) mengatakan strategi active learning merupakan sebuah kesatuan sumber kumpulan strategi pembelajaran yang komprehensif, meliputi berbagai cara untuk membuat peserta didik menjadi aktif. Pada dasarnya aktif learning berusaha untuk memperkuat dan memperlancar stimulus dan ransang anak didik dalam pembelajaran, sehingga pembelajaran menjadi hal yang menyenangkan dan tidak membosankan bagi mereka.

\section{Strategi Pembelajaran Aktif Quiz Team}

Strategi pembelajaran Quiz Team merupakan salah satu teknik dalam strategi pembelajaran aktif yang berfungsi untuk menghidupkan suasana belajar secara berkelompok, Quiz Team merupakan salah satu strategi pembelajaran aktif yang berfungsi untuk menghidupkan suasana belajar, mengaktifkan siswa untuk bertanya maupun menjawab pertanyaan dan meningkatkan kemampuan 
tanggungjawab peserta didik terhadap apa yang mereka pelajari melalui cara yang menyenangkan dan tidak membosankan.

\section{Langkah-Langkah}

Strategi

Pembelajaran Aktif Quiz Team

Silberman

(2006:163)

mengungkapkan prosedur dari strategi pembelajaran Quiz Team sebagai berikut:

a. Pilihlah topik yang dapat dipresentasikan ke dalam tiga bagian

b. Bagilah peserta didik menjadi 3 tim

c. Jelaskan bentuk sesinya dan mulailah presentasi. Batasi presentasi sampai 10 menit atau kurang

d. Minta tim A menyiapkan kuis yang berjawaban singkat. Kuis ini tidak memakan waktu lebih dari lima menit untuk persiapan. Tim B dan C memanfaatkan waktu untuk meninjau catatan mereka

e. Tim A menguji anggota tim B. Jika tidak bisa menjawab, Tim $\mathrm{C}$ diberikan kesempatan untuk menjawabnya.

f. Tima A melanjutkan ke pertanyaan selanjutnya kepada anggotan Tim C, dan ulangi prosesnya.

g. Ketika kuis selesai, lanjutkan dengan bagian kedua pelajaran Anda, dan tunjuklah Tim B sebagai pemimpin kuis

h. Setelah Tim B menyelesaikan ujian tersebut, lanjutkan dengan bagian ketiga dan tentukan tim $\mathrm{C}$ sebagai pemimpin kuis.

\section{Hakikat Hasil Belajar}

Menurut Hamalik (2001), guru perlu mengenal hasil belajar dan kemajuan belajar siswa yang telah diperoleh seelumnya, misalnya dari sekolah lain, sebelum memasuki sekolahnya sekarang. Hal-hal yang perlu diketahui itu ialah antara lain penguasaan pelajaran, keterampilan-keterampilan belajar dan bekerja. Membantu mendiagnosis kesulitan belajar siswa, dapat memperkirahkan hasil dan kemajuan belajar selanjutnya.

\section{Pengertian Teks Biografi}

Menurut Fuad (2012:24), teks biografi merupakan riwayat hidup seseorang yang ditulis oleh orang lain. Penulis bertindak sebagai pemilik hak atas kekayaan intelektual atas penulisannya bertanggung jawab atas resiko hukum buku terseut, sementara tokoh yang ditulis hanya sebagai narasumber.

\section{Ciri Teks Biografi}

Fu'ad (2012: 27-28) menuliskan ciriciri biografi yang memikat yaitu:
a. Dibuat Berdasarkan Fakta
b. Isinya Dapat Menginspirasi
c. Memiliki Struktur yang Jelas

\section{Struktur Teks Biografi}

a. Orientasi atau setting (aim), berisi informasi mengenai latar belakang kisah atau peristiwa yang akan 
diceritakan selanjutnya untuk membantu pendengar/pembaca.

Informasi yang dimaksud berkenaan dengan ihwal siapa, dimana, dan bagaimana.

b. Peristiwa kejadian penting (important evevnt, record of event), berisi rangkaian peristiwa yang disusun secara kronologis, menurut urutan waktu, yang meliputi kejadiankejadian utama yang dialami tokoh. Dalam bagin ini mungkin pula disertakan komentar- komentar pencerita pada beberapa bagiannya.

c. Reorientasi, berisi komentar evaluatif atau pernyataan simpulan menganai rangkaian peristiwa yang telah diceritakan sebelumnya. Bagian ini sifatnya opsional, yang mungkin ada atau tidak ada dalam teks biografi.

Berdasarkan uraian di atas peneliti dapat menyimpulkan bahwa teks biografi memiliki tiga struktur yakni Orientasi, Peristiwa kejadian penting,dan reorientasi. Ketiga struktur di atas harus ada di dalam teks biografi.

\section{Pola Penyajian Teks Biografi}

Menurut Kemendikbud (2017:281) Pola teks biografi dibagi menjadi empat yaitu alur cerita, sudut pandang tokoh, gaya penulisan, dan fokus penceritaan, berikut penjelasannya : a. Alur cerita merupakan runtutan cerita baik dari masa lalu ke masa sekarang atau dari masi sekarang ke masa lau, bisa memakai salah satu dari kedua alur itu.

b. Sudut pandang merupakan sudaung pandang yang dipakai seperti sudut pandang orang kedu apabila menggunkan sudut pandang orang pertama itu merupakan autobiografi.

c. Gaya penulisan. Gaya penulisan pada teks biogarafi yaitu deskriptif naratif yang dikombinasi dengan dialog. Sehingga pembaca seperti melihat dan juga merasakan sendiri apa yang sudah deskripsikan penulis.

d. Fokus penceritaan, sedangkan untuk fokus penceritaannya teks biografi yaitu mengenai keluarga, pendidikan, dan karya.

\section{METODE PENELITIAN}

Metode yang digunakan dalam penelitian ini dalah metode eksperimen dengan desain One group Pretest Posttest Design(Sugiyono 2012:111). Model One Group Pre-test and Post-test Design merupakan eksperimen yang dilaksanakan pada satu kelompok saja tanpa pembanding.

\section{HASIL DAN PEMBAHASAN PENELITIAN}




\section{Hasil Penelitian}

Data nilai yang diperoleh dari tes siswa kelas X SMK Negeri 2 Medan adalah sebagai berikut.

awal hasil belajar menelaah teks biografi

Tabel 1

Identifikasi Kecenderungan Hasil belajar menelaah teks biografi sebelum menggunakan Strategi Quiz Team

\begin{tabular}{c|c|c|c}
\hline Rentang & F. Absolute & F. Relative & Kategori \\
\hline $85-100$ & 0 & $0 \%$ & Sangat Baik \\
$70-84$ & 3 & $10 \%$ & Baik \\
$55-69$ & 8 & $26,67 \%$ & Cukup \\
$40-54$ & 10 & $33,33 \%$ & Kurang \\
$00-39$ & 9 & $30 \%$ & SangatKurang \\
\hline & 30 & $100 \%$ & \\
\hline
\end{tabular}

Berdasarkan tabel di atas, maka dapat diketahui bahwa hasil belajar siswa dalam menelaah teks biografi sebelum menggunakan strategi Quiz Team terbagi atas, kategori sangat baik 0 siswa $(0 \%)$, kategori baik sebanyak 3 siswa (10\%), kategori cukup 8 siswa $(26,67 \%)$, kategori kurang 9 siswa $(33,33 \%)$, dan kategori sangat kurang 9 siswa (30\%).Identifikasi hasil belajar menelaah teks biografi siswa sebelum menggunakan strategi pembelajaran aktif Quiz Teamyang paling banyak adalah kurang.

Tabel 2

Identifikasi Hasil Belajar menelaah teks biografi sesudah menggunakan Strategi Quiz Team

\begin{tabular}{c|c|c|c}
\hline Rentang & F. Absolute & F. Relative & Kategori \\
\hline $85-100$ & 10 & $33,34 \%$ & Sangat Baik \\
$70-84$ & 16 & $53,33 \%$ & Baik \\
$55-69$ & 4 & $13,33 \%$ & Cukup \\
$40-54$ & 0 & $0 \%$ & Kurang \\
$00-39$ & 0 & $\%$ & SangatKurang \\
\hline & 30 & $100 \%$ & \\
\hline
\end{tabular}


Berdasarkan tabel di atas, dapat diketahui bahwa hasil belajar siswa dalam menelaah teks biografi sesudah menggunakan strategi Quiz Team terbagi atas, kategori sangat baik sebanyak 10 siswa $(33,34 \%)$, kategori baik sebanyak 16 siswa $(53,33 \%)$, kategori cukup 4 siswa $(13,33 \%)$, kategori kurang 0 siswa $(0 \%)$, dan kategori sangat kurang 0 siswa (0\%).Identifikasi hasil belajar menelaah teks biografi siswa setelah menggunakan strategi Quiz Team yang paling banyak adalah kategori baik.

\section{Pembahasan Penelitian}

Hasil dari data penelitian telah diperoleh, maka berikut akan dijelaskan satu persatu temuan penelitian berdasarkan rumusan masalah.

\section{Hasil Belajar Menelaah Teks Biografi sebelum menggunakan Strategi Quiz Team oleh Siswa Kelas $X$ SMK Negeri 2 Medan Tahun \\ Pembelajaran 2018/2019}

Berdasarkan hasil penelitian, diketahui hasil belajar menelaah teks biografi sebelum menggunakan strategi Quiz Team, memperoleh nilai rata-rata sebesar 47,83 dari jumlah siswa sebanyak 30 orang. Kemampuan tersebut belum mencapai KKM yang telah ditentukan SMK Negeri 2 Medan, yakni sebesar 75.

Adapun kategori pencapaian hasil belajar menelaah teks biografi tersebut termasuk dalam empat kategori, yaitu dalam kategori sangat baik 0 siswa (0\%), kategori baik sebanyak 3 siswa (10\%), kategori cukup 8 siswa $(26,67 \%)$, kategori kurang 10 siswa $(33,33 \%)$, dan kategori sangat kurang 9 siswa 303\%). Dari nilai rata-rata yang diperoleh siswa tersebut, menunjukkan bahwa hasil belajar menelaha teks biografi sebelum menggunakan strategi aktif Quiz Team berada pada kategori kurang.

\section{Hasil Belajar Menelaah Teks} Biografi sesudah menggunakan Strategi Quiz Team oleh Siswa Kelas X SMK Negeri 2 Medan Tahun Pembelajaran 2018/2019

Berdasarkan hasil penelitian, diketahui hasil belajar menelaah teks biografi sesudah menggunakan strategi Quiz Team, memperoleh nilai rata-rata sebesar 79,67 dari jumlah siswa sebanyak 30 orang. Kemampuan tersebut sudah mencapai KKM yang telah ditentukan SMK Negeri 2 Medan, yakni sebesar 75.

Adapun kategori pencapaian hasil belajar menelaah teks biografi tersebut termasuk dalam empat kategori, yaitu dalam kategori sangat baik 10 siswa $(33,34 \%)$, kategori baik sebanyak 16 siswa $(53,33 \%)$, kategori cukup 4 siswa $(33,33 \%)$, kategori kurang 0 siswa $(0 \%)$, dan kategori sangat kurang 0 siswa 0\%). Dari nilai rata-rata yang diperoleh siswa 
tersebut, menunjukkan bahwa hasil belajar menelaha teks biografi sesudah menggunakan strategi aktif Quiz Team berada pada kategori baik.

\section{Efektivitas Strategi Pembelajaran} Aktif Quiz Team terhadap Hasil Belajar Menelaah Teks Biografi Kelas X SMK Negeri 2 Medan Tahun Ajaran 2018/2019

Berdasarkan uraian di atas, diperoleh hasil penelitian yang menunjukkan nilai rata-rata untuk hasil belajar menelaah teks biografi oleh siswa pada tahap sebelum penerapan strategi Quiz Team tergolong pada kategori kurang dengan nilai rata-rata 47,83 sedangkan tahap sesudah diterapkan strategi Quiz Team memiliki nilai rata-rata sebesar 79,67 dan termasuk dalam kategori baik. Sehingga dapat disimpulkan bahwa strategi Quiz Team efektif dalam meningkatkan hasil belajar menelaah teks biografi. Hal ini sesuai dengan hasil yang diharapkan, yaitu meningkatkan hasil belajar siswa bahwa kemampuan menelaah teks biografi sebelum menggunakan strategi Quiz Team lebih rendah jika dibandingkan dengan sesudah menggunakan strategi Quiz Team.

\section{SIMPULAN DAN SARAN}

Berdasarkan hasil analisis yang telah dilakukan dalam penelitian ini, maka dapat disimpulkan bahwa strategi Quiz Teamefektif digunakan terhadap hasil belajar menelaah teks biografi siswa kelas X SMK Negeri 2 MedanTahun Ajaran 2018/2019. Penelitian ini mempunyai populasi seluruh siswa kelas $\mathrm{X}$ SMK Negeri 2 Medan dengan sampel penelitian 30 siswa. Penelitian ini menunjukkan hasil rata-rata keterampilan menulis teks drama siswa sebelum menggunakan strategi Quiz Team (pretest) adalah 47,83 yang termasuk kategori kurang. Berbeda dengan nilai rata-rata yang diperoleh siswa pada saat setelah menggunakan strategi Quiz Team (posttest) yakni 79,67 yang termasuk dalam kategori baik. Berdasarkan simpulan dapat ditarik beberapa saran sebagai berikut, 1.) Pembelajaran menelaah teks biografi dengan menggunakan strategi Quiz Team terbukti efektif sehingga strategi ini dapat menjadi alternatif lain bagi guru dalam melaksanakan pembelajaran menelaah teks biografi di sekolah. 2) Agar tercapainya tujuan pembelajaran, seorang guru seharusnya lebih aktif dan kreatif dalam menggunakan strategi-strategi pembelajaran sesuai materi pembelajaran. Hal tersebut diharapkan dapat meningkatkan kualitas dan kereativitas siswa dalam kegiatan proses pembelajaran.

3) Pada penelitian ini menggunakan desain penelitian one group pretest posttest design. Pada pihak yang ingin melakukan 
penelitian lebih lanjut mengenai menelaah teks biografi, sebaiknya menggunakan desain penelitian yang berbeda.

\section{DAFTAR PUSTAKA}

Asra, Sumiati. 2016. Metode Pembelajaran. Bandung: C.V Wacana Prima

Dimyanti, Mudjiono. 2010. Belajar dan Pembelajaran. Jakarta: Rineka Cipta

Fuad, Zulfikar. 2012. The Secret Of Biography: Rahasia Menulis Biografi Ala Ramadhan K.H.Jakarta: Akademia Permata Hamalik, Oemar. 2001. Proses Belajar Mengajar. Bandung: Bumi Aksara

Hamruni. 2012. Strategi Pembelajaran. Yogyakarta: Insan Madani.

Hisyam, Zaini. 2008. Strategi Pembelajaran Aktif. Yogyakarta: Insan Mandiri

Istarani. 2011. 58 Model Inovatif (Referensi Guru dalam Menentukan Model Pembelajaran. Medan: Media Persada

Kementerian Pendidikan dan Kebudayaan. 2017. Buku Guru Bahasa Indonesia. Jakarta: Pusat Kurikulum dan Perbukuan
Pratiwi, Wiwit. 2014. Penerapan Metode Pembelajaran Quiz Team Untuk Meningkatkan Aktivitas dan Prestasi Belajar Siswa Pada Materi Kelarutan dan Hasil Kali Kelarutan di Kelas XI IPA 2 SMA Al Islam 1 Surakarta Tahun Ajaran 2014/ 2015. Jurnal Pendidikan Kimia. Vol. 5, No. 1 Tahun 2016. Hal 46-54

Silberman, Melvin L. 2007. Active Learning Strategi Pembelajaran Aktif. Yogyakarta: Pustaka Insan Madani

Sugiyono. 2012. Metode Penelitian Pendidikan: Pendekatan Kuantitatif, Kualitatif, dan $R \& D$. Bandung: Alfabeta. 